University of Nebraska - Lincoln

DigitalCommons@University of Nebraska - Lincoln

USDA Wildlife Services - Staff Publications

U.S. Department of Agriculture: Animal and Plant Health Inspection Service

6-10-2021

\title{
Contemporary challenges and opportunities for the management of bird damage at field crop establishment
}

\author{
Christophe Sausse \\ Terres Inovia, France \\ Alice Baux \\ Agroscrope, Switzerland \\ Michel Bertrand \\ Universite Paris Saclay \\ Elsa Bonnaud \\ Universite Paris-Saclay \\ Sonia Canavelli \\ Parana Experimental Station \\ Follow this and additional works at: https://digitalcommons.unl.edu/icwdm_usdanwrc \\ Part of the Natural Resources and Conservation Commons, Natural Resources Management and \\ Seficyextpage for additional a a thor'stal Sciences Commons, Other Veterinary Medicine Commons, \\ Population Biology Commons, Terrestrial and Aquatic Ecology Commons, Veterinary Infectious Diseases \\ Commons, Veterinary Microbiology and Immunobiology Commons, Veterinary Preventive Medicine, \\ Epidemiology, and Public Health Commons, and the Zoology Commons
}

Sausse, Christophe; Baux, Alice; Bertrand, Michel; Bonnaud, Elsa; Canavelli, Sonia; Destrez, Alexandra; Klug, Page E.; Olivera, Lourdes; Rodriguez, Ethel; Tellechea, Guillermo; and Zuil, Sebastian, "Contemporary challenges and opportunities for the management of bird damage at field crop establishment" (2021). USDA Wildlife Services - Staff Publications. 2532.

https://digitalcommons.unl.edu/icwdm_usdanwrc/2532

This Article is brought to you for free and open access by the U.S. Department of Agriculture: Animal and Plant Health Inspection Service at DigitalCommons@University of Nebraska - Lincoln. It has been accepted for inclusion in USDA Wildlife Services - Staff Publications by an authorized administrator of DigitalCommons@University of Nebraska - Lincoln. 


\section{Authors}

Christophe Sausse, Alice Baux, Michel Bertrand, Elsa Bonnaud, Sonia Canavelli, Alexandra Destrez, Page

E. Klug, Lourdes Olivera, Ethel Rodriguez, Guillermo Tellechea, and Sebastian Zuil 


\title{
Contemporary challenges and opportunities for the management of bird damage at field crop establishment
}

\author{
Christophe Sausse $^{\mathrm{a}, *}$, Alice Baux ${ }^{\mathrm{b}}$, Michel Bertrand ${ }^{\mathrm{c}}$, Elsa Bonnaud ${ }^{\mathrm{d}}$, Sonia Canavelli ${ }^{\mathrm{e}}$, \\ Alexandra Destrez ${ }^{\mathrm{f}}$, Page E. Klug ${ }^{\mathrm{g}}$, Lourdes Olivera ${ }^{\mathrm{h}}$, Ethel Rodriguez ${ }^{\mathrm{h}}$, Guilllermo Tellechea ${ }^{\mathrm{h}}$, \\ Sebastian Zuil ${ }^{\mathrm{i}}$ \\ a Terres Inovia, France \\ ${ }^{\mathrm{b}}$ Agroscope, Switzerland \\ ${ }^{\text {c }}$ UMR Agronomie INRAE, AgroParisTech, Université Paris-Saclay, France \\ ${ }^{\mathrm{d}}$ Ecologie Systématique Evolution, Université Paris Sud, AgroParisTech, Université Paris-Saclay, CNRS, France \\ ${ }^{\mathrm{e}}$ INTA, Parana Experimental Station, Argentina \\ ${ }^{\mathrm{f}}$ AgroSup Dijon, Centre des Sciences du Goût et de l'Alimentation, France \\ ${ }^{g}$ US Department of Agriculture, Animal and Plant Health Inspection Service, Wildlife Services, National Wildlife Research Center, North Dakota State University, \\ Department of Biological Sciences, Fargo, ND, USA \\ ${ }^{\mathrm{h}}$ INIA-DGSA (MGAP) Agreement, Uruguay \\ ${ }^{\mathrm{i}}$ INTA, Rafaela Experimental Station, Argentina
}

\section{A R T I C L E I N F O}

\section{Keywords:}

Bird damage

Pest birds

Ecosystem disservices

Field crops

Crop emergence

Landscape

Research agenda

\begin{abstract}
A B S T R A C T
Bird damage, from sowing to crop establishment, is an important issue for farmers in many parts of the world. However, reliable and cost-effective solutions remain elusive because management tools and research on the subject are limited. The spatial variability of damage across landscapes and the adaptative behaviour of birds create further challenges. Additionally, the issue must be tackled at the landscape scale and involve a variety of stakeholders with conflicting interests and objectives. We summarize some of the challenges and opportunities identified to face these difficulties and address four major research directions for operational solutions including 1) crop damage assessment, 2) methods and tools development at the landscape scale, 3) coordination of stakeholders, and 4) pest bird ecology in agroecosystems. More fundamentally, we address the question of largescale ecological dynamics that can explain changing damage patterns such as the recent observations of increased damage in Europe. Despite the impact to the agricultural sector, research effort to understand vertebrate pest damage is still modest. We advocate for the creation of networks to share knowledge and feedback and engages multiple stakeholders, including ecological and agricultural researchers, farmers, and policy makers.
\end{abstract}

\section{Introduction}

Farmers request research and development to provide solutions to prevent bird damage from sowing to maturity. In recent years they have indicated increased damage during crop establishment in Europe and some regions of the Americas. Few cost-effective solutions are available for farmers with an acceptable cost/benefit ratio. Moreover, there is a paucity of human and funding resources devoted to this topic due to contrasting or conflicting interests, competences, and objectives of agronomic and ecological agencies. The number of private and public stakeholders (e.g., agriculture, wildlife conservation, and hunting) increases coordination costs and may delay research effort. Additionally, the inclusion of lethal control tools can be controversial when conservation of declining native bird populations is of significance. Thus, the development of non-lethal strategies is an emphasis for damage reduction tools and methods.

In this perspective paper, we highlight the issue of damage before and during crop emergence, explore the potential causes of changing damage patterns, and suggest research avenues based on pest-specific natural histories. This article continues a work started in a video-call workshop conducted in March 12, 2019 to share experience about bird damage to extensive crops and draw guidelines for future

\footnotetext{
* Corresponding author.

E-mail address: c.sausse@terresinovia.fr (C. Sausse).
} 
collaboration (Annex A). The scope of this article is damage at the establishment of cereals, pulses, and oilseed crops, caused by birds. In the first section, we briefly present the prevalence of the issue, the lack of effective solutions, and the characteristics that distinguish vertebrate pest damage from other crop protection issues. In the second section we discuss broad-scale strategies beyond the field that are necessary to effectively respond to the challenges of damage management. We also identify knowledge gaps that need to be addressed to implement these strategies. Finally, we explore some of the difficulties to address this topic by traditional knowledge areas such as ecology and agronomy. Even when we focus on bird damage at crop establishment, most concepts and strategies, as well as challenges and opportunities, also apply to damage management from sowing to crop maturity. Finally, the article deals mainly with tools and methods that can be used by farmers, without going deep into the essential issues of management at regional and national level.

\section{A situation of concern}

\subsection{The importance of bird damage at crop establishment}

Table 1 summarizes current problems caused by birds in field crops at emergence in some countries of North and South America and Europe. Damage before and during crop emergence caused by Corvidae and Columbidae is a major issue in Western Europe on Spring crops (Table 1), although other cases are noted on cereals (Sturnidae, Gruidae). Farmers across Northern Europe may suffer from waterfowl (Anatidae) and crane (Gruidae) damage on cereals, and in some cases on grasslands (Table 1). In southern South America (Argentina and Uruguay), Columbidae are the main nuisance species in emerging crops, although damage by other bird families (e.g., Anatidae) have been reported in some regions. Due to various ecological and agricultural conditions across North America damage at emergence is impacted by a variety of bird families (i.e., Gruidae, Anatidae, Phasianidae, Laridae, Alaudidae, Sturnidae, Corvidae, and Icteridae) and is of concern in numerous crops (Table 1). The damage period and susceptible stages vary according to pest species and crops. Damage from Corvidae can occur from sowing to the stage 4-5 leaves (Thibord and Cabeza-Orcel 2020). Damage from Columbidae occurs within a short period, one to two weeks after emergence (Sausse et al., 2021 in this issue). Anatidae may consume green matter as soon as leaves develop, and the preferred height sward varies among species (Fox et al., 2017). Damage can be more severe when crops have little compensation capacity (e.g., maize and sunflower).

Damage at early crop stages has long been recognized but is usually less reported than damage at crop maturity. The worldwide review by
De Grazio (1978) on bird damage reported damage at maturity $(n=69)$ more often than damage at emergence $(n=11)$. Nevertheless, the prevalence and severity of damage at emergence may have changed in recent years. In particular, the damage at emergence was not documented in the international review of bird damage in sunflower by Linz and Hanzel (1997). Western Europe may be experiencing a reversal of the priorities, from maturity to emergence, according to feedback from technicians, advisory services, farmer complaints, and recent studies (Sausse et al., 2021 in this issue, Lamichhane 2021). Waterfowl damage has also increased in recent decades in Northwest Europe (Fox et al., 2017; Montràs-Janer et al., 2019). Bird damage at field crop establishment has a direct impact on crop production (e.g., yield losses, reseeding costs). This impact is caused by the consumption of seeds and seedlings, but also by soil trampling and puddling in the case of waterfowl (Fox et al., 2017). Damage also has indirect impacts such as the costs of crop protection and monitoring and opportunity lost when producers abandon crops due to risk of bird damage. These indirect impacts were documented for sunflower in North America (Kleingartner 2003; Klosterman et al., 2013 for damage at maturity) and reported by farmers and technicians in Argentina, Uruguay, and France. Removing a crop from the rotation due to bird damage has potential economic and environmental consequences. A restriction in the number of crop species cultivated is indeed contrary to an agronomic approach that recommends crop diversification for economic and environmental benefits (Beillouin et al., 2019).

The reviews that mention damage at crop establishment (De Grazio 1978; Bruggers et al., 1978; Fox et al., 2017) emphasize the low level of evidence both for qualification and quantification of damage; they use grey literature in national languages and figures whose origin cannot always be traced (case reported by Bruggers et al., 1998). The few references cited in Table 1 are heterogeneous. They come from grey literature, reviews, field studies and analysis of existing databases. They provide fragmentary information, which in our view is not complete. The case of damage at crop establishment is less documented than that of damage at maturity (e.g., economic assessment by Ernst et al., 2019 on sunflower and Klosterman et al., 2013 on sunflower and maize).

\subsection{Current solutions for farmers are not cost-effective}

Eliminating unwelcome wildlife visitors appears to be an obvious solution for many producers. However, lethal culling operations, when allowed by local regulation, suffer from many disadvantages, such as public resistance, cost inefficiencies, and risks to nontarget wildlife (Linz et al., 2015). Even in the most efficient scenario, lethal management only provides temporary relief (Linz et al., 2015). Additionally, to apply

Table 1

Main problems encountered in some countries of the Americas and Europe at field crop establishment. The table is not comprehensive. It displays our expertise to hierarchise and identify problems of bird damage to annual crops (cereals, pulses and oilseeds). All countries may also experience significant problems with other bird families.

\begin{tabular}{|c|c|c|c|c|}
\hline Country & Family & Species & Crop & Reference \\
\hline \multirow[t]{5}{*}{ USA } & Icteridae & $\begin{array}{l}\text { Agelaius phoeniceus, Quiscalus quiscula, } \\
\text { Xanthocephalus xanthocephalus }\end{array}$ & Corn, rice, sunflower, grains & Wilson et al. (1989) \\
\hline & Anatidae & $\begin{array}{l}\text { Anas platyrynchos, Anser caerulescens, Branta } \\
\text { canadensis }\end{array}$ & $\begin{array}{l}\text { Soybean, corn, rice, sunflower, } \\
\text { canola, grains }\end{array}$ & $\begin{array}{l}\text { Schaible et al., (2005) Conover (1988) Radtke et al., } \\
\text { (2011) Fleger et al., (1987) }\end{array}$ \\
\hline & Gruidae & Antigone canadensis & & McIvor and Conover (1994) Austin et al., (2018) \\
\hline & Alaudidae & Eremophila alpestris & & $\begin{array}{l}\text { Schilinger and Werner (2016) Clark and Hygnstrom } \\
\text { (1994) }\end{array}$ \\
\hline & Phasianidae & Meleagris gallopavo, Phasianus colchicus & & Tefft et al. (2005) \\
\hline Argentina Uruguay & Columbidae & $\begin{array}{l}\text { Zenaida auriculata, Patagioneas maculosa, } \\
\text { Patagioenas picazuro }\end{array}$ & Soybean, sunflower & Bruggers et al., (1998) Bou et al., (2016) \\
\hline \multirow[t]{3}{*}{$\begin{array}{l}\text { France Switzerland } \\
\text { Italy }\end{array}$} & Columbidae & Columba palumbus, Columba livia & $\begin{array}{l}\text { Sunflower, pulse crops, oilseed } \\
\text { rape, grains }\end{array}$ & $\begin{array}{l}\text { Sausse et al., (2017) Sausse et al., (2021) Lamichhane } \\
\text { (2021) Robin (2011) }\end{array}$ \\
\hline & Corvidae & $\begin{array}{l}\text { Corvus corone, Corvus frugilegus, Corvus } \\
\text { monedula }\end{array}$ & Corn, sunflower, grains & Robin (2011) Sausse et al., (2017) \\
\hline & Sturnidae & Sturnus vulgaris & Grains & Robin (2011) \\
\hline \multirow{2}{*}{$\begin{array}{l}\text { Scandinavia, UK, } \\
\text { Netherland }\end{array}$} & Gruiidae & Grus grus & Barley, wheat & Montràs-Janer et al. (2019) \\
\hline & Anatidae & Branta leucopsis Anser anser (and other) & Barley, wheat & Montràs-Janer et al., (2019) Fox et al., (2017) \\
\hline
\end{tabular}


adaptive management to maintain sustainable wildlife populations along with damage reduction requires large-scale planning and is complicated when the distribution and abundance of the target species varies over space and time, e.g., Runge and Sauer (2017), in the case of blackbirds (Icteridae).

Several repellents for coating seeds or spraying vegetation have been evaluated since the 1960s (Clark 1998). Although some repellents have been tested with success (e.g., anthraquinone for seed protection; Barzen and Ballinger 2018), other studies show a weakening of the protection effect when moving from the aviary to the field (Kaiser et al., 2020; Esther et al., 2013), and specific difficulties for use on seedlings (Esther et al., 2013). Few repellent products are approved, and the development of new products may be cost-prohibitive (Eiseman et al., 2011). Thus, the trend is towards their decline (e.g., no active ingredient is approved in France on sunflower, only one on corn, i.e. ziram for seed treatment). Scaring birds is another strategy. Human scaring may be effective (Simonsen et al., 2016; pink-footed geese, Anser brachyrhynchus), but as part of a management scheme integrated with subsidies or accommodation. Lethal scaring was proven to be effective in the case of the greylag goose (Anser anser; Månsson, 2017). Visual and/or acoustic bird scarers are commonly used, but they are time consuming, and their effectiveness is difficult to assess in the absence of legitimate controls and robust bird counts and behavioral analyses (Avery and Werner 2017). Farmer feedback indicates that the efficacy of deterrent devices is variable and tends to decrease when birds become tolerant of the disturbance (Avery and Werner 2017). However, the use of drones and the possibility of artificial intelligence will allow autonomous flight to target the pest species in real-time, reducing labor constraints (Egan et al., 2020; Klug 2017). Progress is also being made on the improvement of audible signals and on camouflaging of emerging seedlings by cover crops (e.g., barley or faba bean to protect sunflower is under study in France). A problem raised by these field-scale methods is the possibility that the protection of one field may result in a degradation of neighboring fields, if birds move to adjacent, unprotected fields to forage. Labor intensity of the tools and methods should also be considered because tool deployment is time consuming and may require a high level of technical skill to maintain (e.g. Rodriguez et al., 2011). Feedback on bird management indicates that the solution does not lie in a silver bullet but rather in an integrated and adaptive pest management strategy. The design of the strategy depends on the damage scenario, including the crop, time of season, landscape, and pest species.

\subsection{Some biological processes make the problem difficult to solve}

Bird damage to crops, whether they occur at crop emergence or maturity, has three characteristics which make it difficult to quantify and predict. First, bird home ranges can be extensive (several $\mathrm{km}^{2}$ ), and birds spend only part of their time foraging inside crop fields (except for some farmland bird specialists like Alaudidae, many nuisance species of concern usually nest and roost outside the fields). Understanding why some areas are damage trouble spots involves considering the surrounding agricultural landscape, but also more distant land cover types and land uses preferred by birds (e.g., Clergeau 1995). For example, cities and peri-urban areas have become favourable locations for the reproduction of wood pigeons (Columba palumbus) in Eastern and Western Europe, which can then spill over into the surrounding countryside, (e.g., Slater 2001, in England). This phenomenon is also seen in invasive European starlings (Sturnus vulgaris) in North America (Klug and Homan 2020). Furthermore, the demography of migratory birds depends on the management of wintering, stopover, and breeding areas, which can be distant from each other. These broad scales require the coordination of various stakeholders who are not accustomed to working together, such as farmers, hunters, wildlife protection associations, and public authorities governing rural and urban areas. For these reasons, the effectiveness of prevention measures on a given field will depend on the natural and social context, greatly reducing the autonomy of the farmer.

Secondly, birds have cognitive abilities that enable them to interpret and adapt to their environment. It takes them little time to understand that sound scaring is not dangerous (Bishop et al., 2003), or that repellents do not make the seeds inedible (Werner et al., 2010). The effectiveness of preventive measures is therefore variable over time (days or even hours). Additionally, in the mid- and long-term, birds can respond to changes in food sources at landscape scale, which may call into question prevention strategies developed in a supposedly fixed landscape context.

Finally, crop damage is not evenly distributed with a small number of heavily attacked fields, and several fields with no or low damage (Klosterman et al., 2013; Canavelli et al., 2014; Sausse et al., 2021 in this issue). Damage also varies between years, probably in relation to the abundance and distribution of pest species with regional changes in land use/land cover and climatic variables (Calamari et al., 2019; Forcey et al., 2015). The heavy-tailed distribution of risk and the difficulty in predicting damage severity is a frustrating situation for farmers that may lead to abandoning vulnerable crops. On the other hand, research needs to produce reliable estimates of crop damage, bird distribution and abundance, and to link the variation to environmental variables (e.g., landscape features including other crops). Capturing birds in the act of depredating crops is often difficult to achieve, requiring advanced methods of surveillance (e.g., game cameras, Dieter et al., 2014, or radar for large flocks, Clark et al., 2020). In other words, the damage patterns and their cause make studying bird damage data intensive and costly, which in turn reduces the available knowledge for applied solutions.

\section{Challenges and opportunities for advances}

\subsection{Concepts and strategies for an approach beyond the field scale}

Understanding why and how birds consume crops is essential for designing and testing cost-effective damage prevention methods. Bird damage is the result of processes operating at nested spatial and temporal scales, following a classical "hierarchical principle" in ecology (Allen and Starr 1982). Clergeau (1995) and Fox et al. (2017) applied this principle to bird damage, respectively in the case of European starling (Sturnus vulgaris) and waterfowls. It is important to consider three scales at which birds make choices: 1 ) regions occupied across the avian annual cycle, which will determine a pool of birds likely to cause damage, 2) the landscape in which they select roost sites and daily foraging grounds including crop fields, and 3) the fields where they forage. Field-scale methods are rarely effective and could be detrimental to neighboring fields. Regional planning (population and habitat management) requires the involvement of different actors on the long term. From the farmers point of view, the intermediate scale of the landscape seems to be particularly relevant for planning damage prevention during the cropping season.

In terms of the energy needs of birds, it is possible to establish several non-exclusive prevention scenarios at the landscape level, without population regulation. The daily consumption of plants results from the meeting between a supply of food resources, cultivated or not, and the daily bioenergetic demands of birds. The birds solve this energetic problem by selecting resources according to their relative interests (e.g., Peer et al., 2003 for application to blackbirds, Fox et al., 2017 to waterfowls). According to this theoretical framework, one strategy of damage prevention is to increase the availability of a preferred crop in the landscape, so that it exceeds the population capacity to consume it ("dilution" of the damage). This can be done by 1) coordinating sowings in which fields of the susceptible crop reach the same stage at the same time, 2) by increasing the cultivated areas to dilute damage (e.g. Lindell et al., 2016 for cherry orchard, Besser 1978 for sunflower). Another strategy is to sow (or raise seedlings) when other preferred foods are available or bird demand is lower due to phenology or physiological demands (e.g., non-migration and non-breeding seasons). The last 
strategy is to make the crop less attractive by dispersing birds with a combination of frightening devices and alternative food resources (either sown or semi-natural) to draw the birds away from the protected crop (Hagy et al., 2008).

Several studies have demonstrated the value of these strategies through correlative surveys or modelling approaches. However, few have tested changes in practice. Increasing the cultivated area was proven to be effective according to observational surveys (e.g., Lindell et al., 2016; Besser 1978). However, it would produce extra-economic and environmental costs, depending on the induced changes in production systems according to local conditions. For example, the crop rotation makes it possible to increase the area of a single crop in one or more farms a given year without disturbing the total area of the crops for several years. But this strategy prevents to benefit, or to guard against, price fluctuations between years, and maybe detrimental in some cases to environment (i.e., erosion, biodiversity). Synchronisation of sowing and sowing at the right time are currently recommendations resulting from in-field studies and surveys (Klosterman et al., 2013; Klug 2017) or modelling (Clark et al., 2020). Delaying the planting of rice in the southern United States reduces blackbird damage given overwintering flocks have migrated north and dispersed to breeding territories later in the spring (Wilson et al., 1989). Given the difficulties for coordination and the fluctuations in weather conditions, coordinated sowing between farmers is not without difficulty. However, the synchronisation of emergence would be simpler to achieve than synchronisation of maturity because factors impacting the cycle early in the growing season (Lamichhane et al., 2018) are fewer than the factors impacting the cycle throughout the whole season. Evading strategies have been implemented to avoid damage at maturity in the northern Great Plains of the US (e.g., decoy crops, Hagy et al., 2008), perennial sunflower for blackbirds (Linz et al., 2014), and cattail roost management (Linz and Homan 2011). In Northern Europe, Bavéco et al. (2017) used species distribution and resource depletion models to design reserves for waterfowl, offering them alternative resources to crops. This strategy remains to be adapted to the southern European landscape to prevent damage from Columbidae and Corvidae at emergence (e.g., sown and sacrificed strips of sunflower/peas under study in France). Artificial nests and perches are also possible to attract predators, but to our knowledge, no tests have been documented in the context of management of bird damage to field crops, only fruit orchards (Lindell et al., 2018). In all cases, the implementation of these strategies involves local spatial optimization. For example, the location of alternative resources is as important as their total quantity in the managed territory.

\subsection{Knowledge gaps and recommendations}

First, the establishment of a proof of damage, if possible quantified and monetised, is important for the consideration of the bird damage issue in public policies and research strategies. Moreover, damage evaluations (and not only the number of birds), should be reinforced to assess the efficacy and efficiency of management alternatives applied by farmers (Jiguet 2020; Fox et al., 2017). Few data are available on the extent and magnitude of bird damage at field crops establishment worldwide. Obtaining such data involves solving methodological issues. It is indeed difficult to obtain correct damage imputation and large-scale damage quantification simultaneously. The identification of characteristic bird damage symptoms at emergence is more difficult than that at maturity. This is because pests other than birds (e.g., slugs, moles, voles) can cause similar symptoms as well as production issues (e.g., incorrect seed drill settings, low germination rates, and poor soil conditions such as ephemeral wetlands and salinity). Exclusion nets or time lapse cameras may facilitate damage imputation to birds but only on a few fields, while the heavy-tailed distribution of damage requires data on a large number of fields to obtain significant assessments at the regional level. Participative surveys are not totally adapted for that purpose, as only the farmers concerned by damage wish to engage. These surveys do not always provide information about the absence of damage, which does not allow to calculate the percentage of damaged fields. Declarations for insurance may yield more data but their completeness depends also on the willingness to declare (Montràs-Janer et al., 2019; McKee et al., 2021). Remote sensing data can be used to locate and quantify damage to crop caused by vertebrates within fields (Fisher et al., 2019 for wild pig, Sus scrofa). Private companies already propose such services to produce data for insurance companies, but it does not solve the problem of damage imputation without on field expertise. A large-scale deployment would require the treatment of lower resolution data but has yet to be developed in the case of vertebrate damage (but Sarvia et al., 2020 for the assessment of damages from hailstorms based on satellite data).

Secondly, the adaptation and implementation of broader scale strategies are hampered by a lack of applied knowledge on the ecology of the pest birds in agroecosystems. As seen above, the concepts of energy balance and food selection at different scales are the cornerstones of strategies at the landscape scale. To make it useful, we need to consider specificities of agricultural landscapes. These are subject to sudden breaks (e.g., soil tillage, sowing, crop growth and harvest) at several times during the year. The efficacy of evading strategies is therefore a question of timing, all the more than damage may occur on a short period. It is therefore important to predict bird pressure at the beginning of and during the growing season, to facilitate farmers decisions at different time and spatial scales: what is the level of risk this year? When and where to sow? When and where to scare? This bird pressure depends on extrinsic factors (landscape characteristics, changes in crop and natural resources, competitors and predators) and intrinsic factors (abundance and physiological needs of birds according to their breeding status). The dynamics of some of these factors are poorly understood, or at least not easily accessible by farmers and their advisors. They may have accurate information on farming practices, but much less on natural resources and the status and needs of bird populations. Studies on this subject require skills in bird population dynamics and ecology, and data on abundance and phenology. Existing databases from wildlife agencies, bird protection and hunting associations could be shared for this purpose. However, this may raise a problem of confidence among actors because these data are usually produced for private and nonacademic purposes and are possibly controversial when including damage assessments for compensation or the authorisation of lethal control. Open data could help, although there are wide variations between countries. But in practice many datasets are not visible through search engines, and much time is spent in searching datasets, bilateral agreements, unsupported formats, and pre-treatments.

Another important question is what processes are responsible for the spatial patterns of crop consumption in the landscape. The problem can be tackled at the individual scale (e.g., with GPS tracking of birds, Dokter et al., 2018 for an application to goose). Inter and intraspecific interactions are also possible, as birds can exchange information on productive foraging grounds (Ward and Zahavi 1973) and are distributed in space according to their fear of being predated (i.e., "landscape of fear"; Laundre et al., 2010). The heavy-tailed distribution of damage may indicate a cumulative process inherent in flocking and roosting bird species. The number of birds coming to feed on a field would depend on 1) the quality of nearby roosting habitat supporting large number of birds (e.g. Calamari et al., 2019) and 2) the number of birds that have already landed indicating to newcomers that the field is suitable for foraging (Galef and Giraldeau 2001).

The knowledge gap also concerns the sensory ecology and ethology of birds for food selection at the field scale. For example, farmers and technicians observe that corvids can detect invisible buried seeds and then follow the sowing lines. This behaviour can be the subject of two interpretations. The first one is based on remote detection, which indicates the buried seeds, for example, via olfactory signals. The second interpretation is based on learning: birds associate the passage of a seed drill and/or the surface condition with the presence of seeds, and their experience of the geometry of the sowing (parallel lines) enables them to 
probe to soil for seeds more effectively. The high cognitive performance of corvids makes this scenario quite plausible (Taylor 2014) but has been observed in other bird families (Alaudidae) that are not as well recognized for their cognition abilities (Schillinger and Werner 2016). From this perspective, the question is not to know how the birds simply react, but to know how they learn.

Extensive literature and knowledge about bird species' biology, ecology and behaviour, has been generated in Europe on rooks (Corvus frugilegus; Feare 1974), wood pigeons (Murton 1965), and waterfowl (Fox et al., 2017), in the USA on blackbirds (Linz et al., 2017; Orians and Angell 1985), and in Argentina on eared doves (Zenaida auriculata; Murton et al., 1974) and monk parakeets (Myiopsitta monachus; Bucher et al., 1991). However, the use of this literature in informing strategies and tactics to manage bird damage remains limited. Practitioners do not know how to use this knowledge to inform contemporary management decisions. We realize that extrapolating conclusions to various conflict scenarios is problematic due to wide variations between pest species, target crops, and varying landscapes, especially natural or human-modified environments (e.g., habitat-species models for farmland bird conservation should be used locally; Whittingham et al., 2007). Moreover, historical data may become obsolete if environmental conditions change, such as climate and land use/land cover (e.g., bird diets depend on agriculture land cover; Wilson et al., 1999) or if migratory phenology changes with climate (Buskirk et al., 2009). For these reasons, it is important to conduct site-specific biological studies relative to season and year. More importantly, proposing research questions linking bird ecology and behaviour to the occurrence of damage and the consequences of management decisions is necessary.

More fundamentally, the origin of long-term changes, like the aggravation of damage at emergence in Western Europe, remains to be clarified. There are many working hypotheses: bird demographic change (e.g., increase of wood pigeon and waterfowl populations in Europe); exploitation of changing resources corresponding to changes in production systems (e.g., decline in natural areas and agricultural grasslands lead farmland birds to exploit crops) or changing agricultural practices (e.g., earlier sowing dates as observed in South America); abandonment of chemical seed and soil treatments due to pesticide regulation (e.g., carbamate insecticides known to repel birds are forbidden); or weakening of top-down regulation by predators in connection with hunting practices.

\subsection{From fields to managed territories: a need for new methodologies and institutional arrangements}

However attractive on paper, large-scale strategies raise practical obstacles. Proving the effectiveness of strategies involves collecting data to link the prevention practices, their impact on bird damage and activity, and the contextual environmental, agronomic and socioeconomic drivers of damage. The heavy-tailed distribution of damage makes this monitoring strategy costly because surveys on bird damage require a large sample of fields. Digital technologies may reduce the cost of data acquisition at this scale. For example, the satellite Sentinel time series allow to map the crops and their approximate sowing dates at the field level (as already proposed by at least one company in Europe and North America). Moreover, numerous participatory mapping tools enable peer-to-peer exchange of spatially explicit observations and are used, for example, for biodiversity projects (e.g., Couvet et al., 2008). Finally, the traceability of farmers' practices is being developed for internal regulatory and management needs. In our view, the major challenge lies in the communication between these different layers of data thanks to common ontologies (i.e. data representation and organization) and, above all, a sufficient degree of trust between stakeholders in the territory to share their information. To identify blocking points and facilitate interactions between stakeholders it is important to involve social scientists to the research and extension teams in these issues, such happened with Integrated Pest Management (ENDURE 2010; Heong et al., 2020).

Agronomists use the factorial experimentation to provide evidence at field scale. Testing practices to prevent bird damage involves other methods, because comparisons "all things being equal" are impossible in this case. Fields are subject to gradients of bird crop consumption, e.g., from the periphery of the fields to their centre (Canavelli et al., 2014). Furthermore, the effectiveness of a method will strongly depend on environmental conditions (the number of birds present locally, their gregarious behaviour, the availability of alternative resources at a particular time of the year). For these reasons, results under controlled conditions are difficult to repeat in the field or when moving from the aviary to the field test. Finally, the heavy-tailed distribution of attacks requires repeating the experiments on many fields to ensure situations with enough bird pressure, with subsequent costs. To overcome these difficulties, it is suggested to work on field networks of very well-planned case studies, with the collection of data about relevant environmental variables.

Landscape studies usually rely on surveys and correlative methods. The output tendencies are helpful to build hypotheses but not sufficient to build operational prevention strategies and to prove that these strategies are efficient. Testing territorial approaches like those proposed in the previous section implies defining a control: comparing damage in other 'untreated' territories can be misleading if the environmental conditions are different. One solution could be to compare trajectories (i.e., the evolution between years of damage between treated and untreated territories or treated areas before and after the control is implemented). Before the test, modelling to assess the impact of management options could be useful (e.g., Clark et al., 2020 for harvest dates, Baveco et al., 2017 for the dimensions of reserved areas).

This technical analysis brings us to a second obstacle: who can carry and coordinate such territorial projects? We agree on the fact that there is not a ready-made formula or directly applicable scheme for all the situations. Different stakeholders, agricultural farmers, hunters, environmental protection association members, and governmental agents (both from agricultural and wildlife agencies), do not always have the same objectives. Studies on the subject will have to be adapted to the institutional and sociological context, which may vary between countries. The United States has a dedicated administration (United States Department of Agriculture, Wildlife Services [USDA-WS]) that can be called upon by various stakeholders, while the USDA WS National Wildlife Research Center is tasked with researching methods and tools to manage human-wildlife conflict. France relies on "co-management" where the state brings together stakeholders to collaborate on prevention strategies and to conduct studies if necessary. Since 2011 Uruguay has been implementing a public policy to combine resources from the Ministry of Agriculture and the National Institute of Agricultural Research (INIA) that includes agreements with the private sector to develop management tools.

\subsection{A topic difficult to classify}

It seems paradoxical that, at a time when agronomy is addressing the subjects of agroecology, biodiversity and landscape ecology, research efforts on bird damage to crops seem globally modest, without consideration of possible variations between countries. The subject is singular and difficult to fit into the classical conceptual frameworks of crop protection. While other bioagressors (i.e., insects, weeds, and diseases) are considered detrimental to crops, native birds are often seen through the issues of biodiversity conservation and ecosystem services and disservices. From our experience, ecologists, who are often motivated by species conservation, may not find the topic of bird damage very attractive or they fear to be involved in a debate on lethal culling. Agronomists find the topic frustrating, because operational results are weak when compared with other domains of crop protection. For most agronomists and decision makers, the pest birds are a problem that they must live with, willingly or unwillingly, without means of control. The 
reason for this paradox probably lies in an in-depth analysis of the history of scientific disciplines, which is out of the scope of this paper. We can nevertheless propose some explanations from our experiences.

The first argument is practical. The subject is particularly complex and requires data-intensive methods. The variability of natural phenomena cannot be reduced to laboratories or field trials, which challenges agronomists given these methods are usually well suited to work on other pests and diseases. This argument can now be partially removed because the lower data cost and the profusion of geographical information is changing the way we look at landscape.

Secondly, birds are charismatic species, and it is problematic for citizens and ecologists to classify some of them as "pests" even if in urban areas some of the negative effects of their presence are admitted. The debate usually revolves around one question: is it allowed to kill birds to protect agricultural crops? We consider that this debate should be shifted from species to agroecosystem management. This holistic framework does not prohibit the regulation itself but subordinates these practices to a global analysis and systematic assessments (Jiguet 2020). It is probable that the recent increase of crop damage at early crop stages has something to do with the simplification of landscapes, and processes of biotic homogenization including the decrease of birds of prey. This fundamental questioning opens a convergence between crop protection and wildlife conservation (e.g., Cumming and Spiesman 2006), with the future development of smart solutions far away from a "Kill Them All" strategy.

Finally, the subject may appear too specific according to agricultural sustainability issues, and it does not fit into the right boxes of multifunctional agroecosystems. On the contrary, we believe that bird damage has systemic and global effects because it is a driver of crop diversity, with all the impacts that can result from it. We also contend that a particular and applied topic, such as finding a solution to bird damage, is more likely to interest local actors than global approaches on multifunctionality. However, it could be a starting point for other works at the landscape scale, particularly if it is related with other pest management approaches, such as Integrated Pest Management at the regional scale (Ehler 2006) or Area Wide Pest Management (Koul et al., 2008).

\section{Conclusion}

The methodological challenges and the small number of research teams working on bird damage worldwide underscore the importance of creating networks to allow the sharing of knowledge and feedbacks in a framework associating multiple stakeholders, including researchers (ecologists, agronomists, and socio-economists) farmers, and policy makers. To be effective, this approach must encompass the entire production chain, both at the farm and regional scale. In this sense, publicprivate cooperation is essential, with an important role of public institutions and farmers associations at multiple levels (local, national and international), linking multiple actors with a common view and objective, such as the sustainable production of crops in a particular region.

\section{ANNEX A: participants to the 2019 workshop on bird damage to extensive crops}

Corentin Barbu, Sahar Abib (INRAe UMR Agronomie, France), Christophe Sausse, Myriam Lévy (Terres Inovia, France); Sonia B. Canavelli, Sebastian G. Zuil (INTA, Argentina); Fernando Pellegrini, Stefano Carlesi (Scuola Superiore Sant'Anna, Italy); Alice Baux (Agroscope, Switzerland); Page Klug (USDA, NWRC, USA).

\section{Declaration of competing interest}

The authors declare that they have no known competing financial interests or personal relationships that could have appeared to influence the work reported in this paper.

\section{Acknowledgements}

We would like to thank for their participation in the 2019 workshop Corentin Barbu of INRAe UMR Agronomy and Fernando Pellegrini of the University of Pisa. We also thank the reviewers, especially for sharing references about the case of Anatidae in Northern Europe.

\section{References}

Allen, T.F., Starr, T.B., 1982. Hierarchy: Perspectives for Ecological Complexity. University of Chicago Press Chicago, USA.

Austin, J., Morrison, K., Harris, J., 2018. Cranes and Agriculture: a Global Guide for Sharing the Landscape. International Crane Foundation, Baraboo, Wisconsin, USA, p. 303.

Avery, M.L., Werner, S.J., 2017. Frightening Devices. In: Linz, G.M., Avery, M.L., Dolbeer, R.A. (Eds.), Ecology and Management of Blackbirds (Icteridae) in North America. CRC Press/Taylor \& Francis, Boca Raton, FL, USA, pp. 159-174.

Barzen, J., Ballinger, K., 2018. Effective and sustainable prevention of avian damage to planted seeds through seed treatment. Proceedings of the North American Crane Workshop 14, 89-100. In: https://digitalcommons.unl.edu/nacwgproc/367.

Baveco, J.M., Bergjord, A.K., Bjerke, J.W., Chudzińska, M.E., Pellissier, L., Simonsen, C. E., Madsen, J., Tombre, I.M., Nolet, B.A., 2017. Combining modelling tools to evaluate a goose management scheme. Ambio 46 (2), 210-223.

Besser, J.F., 1978. Birds Ans Sunflower. In: Carter, J.F. (Ed.), Sunflower Science and Technology. Agron. Monogr. 19. ASA, CSSA, and SSSA, Madison, WI, USA, pp. 263-278.

Beillouin, D., Ben-Ari, T., Makowski, D., 2019. Evidence map of crop diversification strategies at the global scale. Environ. Res. Lett. 14, 123001.

Bishop, J., McKay, H., Parrott, D., Allan, J., 2003. Review of International Research Literature Regarding the Effectiveness of Auditory Bird Scaring Techniques and Potential Alternatives. Food and Rural Affairs, York, UK.

Bou, N., Dardanelli, S., Olivera, L., Tellechea, G., Addy Orduna, L., Canavelli, S., Rodríguez, E., 2016. Desarrollo de un método para evaluar el daño ocasionado por aves en cultivos comerciales de soja recién emergida. IDESIA 34, 67-74.

Bruggers, R.L., Rodriguez, E., Zaccagnini, M.E., 1998. Planning for bird pest problem resolution: a case study. Int. Biodeterior. Biodegrad. 42, 173-184. https://doi.org/ 10.1016/S0964-8305(98)00046-8.

Bucher, E.H., Martin, L.F., Martella, M.B., Navarro, J.L., 1991. Social behaviour and population dynamics of the monk parakeet. Proc. Int. Ornithol. Congr. 20, 681-689.

Buskirk, J.V., Mulvihill, R.S., Leberman, R.C., 2009. Variable shifts in spring and autumn migration phenology in North American songbirds associated with climate change. Global Change Biol. 15 (3), 760-771. https://doi.org/10.1111/j.13652486.2008.01751.x.

Calamari, N.C., Canavelli, S.B., Cerezo, A., Dardanelli, S., Bernardos, J.N., Zaccagnini, M. E., 2019. Variations in pest bird density in Argentinean agroecosystems in relation to land use and/or cover, vegetation productivity and climate. Wildl. Res. 45 (8), 668-678. https://doi.org/10.1071/WR17167.

Canavelli, S.B., Branch, L.C., Cavallero, P., González, C., Zaccagnini, M.E., 2014. Multilevel analysis of bird abundance and damage to crop fields. Agric. Ecosyst. Environ. 197, 128-136. https://doi.org/10.1016/j.agee.2014.07.024.

Clark, B.A., Klug, P.E., Stepanian, P.M., Kelly, J.F., 2020. Using bioenergetics and radarderived bird abundance to assess the impact of a blackbird roost on seasonal sunflower damage. Human-Wildlife Interactions 14 (3), 427-441.

Clark, J.P., Hygnstrom, S.E., 1994. Horned Larks. The Handbook: Prevention and Control of Wildlife Damage, p. 64.

Clark, L., 1998. Review of Bird Repellents. In: Baker, R.O., Crabb, A.C. (Eds.), Proceedings of the 18th Vertebrate Pest Conference. University of California at Davis, CA USA, pp. 330-337. https://doi.org/10.5070/V418110214.

Clergeau, P., 1995. Importance of multiple scale analysis for understanding distribution and for management of an agricultural bird pest. Landsc. Urban Plann. 31 (1), 281-289. https://doi.org/10.1016/0169-2046(94)01053-B.

Conover, M.R., 1988. Effect of grazing by Canada geese on the winter growth of rye. J. Wildl. Manag. 52, 76-80.

Couvet, D., Jiguet, F., Julliard, R., Levrel, H., Teyssedre, A., 2008. Enhancing citizen contributions to biodiversity science and public policy. Interdiscipl. Sci. Rev. 33 (1), 95-103.

Cumming, G.S., Spiesman, B.J., 2006. Regional problems need integrated solutions: pest management and conservation biology in agroecosystems. Biol. Conserv. 131 (4), 533-543. https://doi.org/10.1016/j.biocon.2006.02.025.

De Grazio, J.W., 1978. World Bird Damage Problems. In: Proceedings of the 8th Vertebrate Pest Conference. University of California at Davis, CA USA, pp. 9-24. http://digitalcommons.unl.edu/vpc8/13.

Dieter, C.D., Warner, C.S., Ren, C., 2014. Evaluation of foliar sprays to reduce crop damage by Canada geese. Human-Wildlife Interactions 8, 139-149.

Dokter, A.M., Fokkema, W., Ebbinge, B.S., Olff, H., van der Jeugd, H.P., Nolet, B.A., 2018. Agricultural pastures challenge the attractiveness of natural saltmarsh for a migratory goose. J. Appl. Ecol. 55 (6), 2707-2718.

Egan, C.C., Blackwell, B.F., Fernández-Juricic, E., Klug, P.E., 2020. Testing a key assumption of using drones as frightening devices: do birds perceive drones as risky? Condor 122 (3), 1-15. https://doi.org/10.1093/condor/duaa014.

Ehler, L.E., 2006. Integrated pest management (IPM): definition, historical development and implementation, and the other IPM. Pest Manag. Sci. 62 (9), 787-789. https:// doi.org/10.1002/ps.1247. 
Eisemann, J.D., Werner, S.J., O'Hare, J.R., 2011. Registration considerations for chemical bird repellents in fruit crops. Outlooks Pest Manag. 22 (2), 87-91. https:// doi.org/10.1564/22apr12.

ENDURE, 2010. Policy Brief No. 1-implementing IPM: a Gradual Path Involving Many Stakeholders. ENDURE Publication.

Ernst, K., Elser, J., Linz, G., Kandel, H., Holderieath, J., DeGroot, S., Shwiff, S., Shwiff, S., 2019. The economic impacts of blackbird (Icteridae) damage to sunflower in the USA. Pest Manag. Sci. 75 (11), 2910-2915. https://doi.org/10.1002/ps.5486.

Esther, A., Tilcher, R., Jacob, J., 2013. Assessing the effects of three potential chemical repellents to prevent bird damage to corn seeds and seedlings. Pest Manag. Sci. 69 (3), 425-430.

Feare, C.J., 1974. Ecological studies of the rook (Corvus frugilegus L.) in North-East Scotland. Damage and its control. J. Appl. Ecol. 11 (3), 897-914. https://doi.org/ $10.2307 / 2401752$.

Fischer, J.W., Greiner, K., Lutman, M.W., Webber, B.L., Vercauteren, K.C., 2019. Use of unmanned aircraft systems (UAS) and multispectral imagery for quantifying agricultural areas damaged by wild pigs. Crop Protect. 125, 104865.

Flegler, E.J.J., Prince, H.H., Johnson, W.C., 1987. Effects of grazing by Canada geese on winter wheat yields. Wildl. Soc. Bull. 15, 402-405.

Forcey, G.M., Thogmartin, W.E., Linz, G.M., McKann, P.C., Crimmins, S.M., 2015. Spatially explicit modeling of blackbird abundance in the Prairie Pothole Region. J. Wildl. Manag. 79 (6), 1022-1033. https://doi.org/10.1002/jwmg.912.

Fox, A.D., Elmberg, J., Tombre, I.M., Hessel, R., 2017. Agriculture and herbivorous waterfowl: a review of the scientific basis for improved management. Biol. Rev. 92, 854-877.

Galef Jr., B.G., Giraldeau, L.A., 2001. Social influences on foraging in vertebrates: causal mechanisms and adaptive functions. Anim. Behav. 61 (1), 3-15.

Hagy, H.M., Linz, G.M., Bleier, W.J., 2008. Optimizing the use of decoy plots for blackbird control in commercial sunflower. Crop Protect. 27 (11), 1442-1447. https://doi.org/10.1016/j.cropro.2008.07.006.

Heong, K.L., Escalada, M.M., Sengsoulivong, V., Schiller, J., 2002. Insect management beliefs and practices of rice farmers in Laos. Agric. Ecosyst. Environ. 92, 137-145.

Jiguet, F., 2020. The Fox and the Crow. A need to update pest control strategies. Biol. Conserv. 248, 108693. https://doi.org/10.1016/j.biocon.2020.108693.

Kaiser, B.A., Johnson, B.L., Ostlie, M.H., Werner, S.J., Klug, P.E., 2020. Inefficiency of anthraquinone-based avian repellents when applied to sunflower: the importance of crop vegetative and floral characteristics in field applications. Pest Manag. Sci. 77, 1502-1511. https://doi.org/10.1002/ps.6171.

Kleingartner, L., 2003. Sunflower losses to blackbirds: an economic burden. Management of North American Blackbirds. Proceedings of a special symposium of The Wildlife Society, 9th Annual Conference USDA-APHIS-Wildlife Services National Wildlife Research Center 13-14.

Klosterman, M.E., Linz, G.M., Slowik, A.A., Homan, H.J., 2013. Comparisons between blackbird damage to corn and sunflower in North Dakota. Crop Protect. 53, 1-5. https://doi.org/10.1016/j.cropro.2013.06.004.

Klug, P.E., 2017. The Future of Blackbird Management Research. In: Linz, G.M., Avery, M.L., Dolbeer, R.A. (Eds.), Ecology and Management of Blackbirds (Icteridae) in North America. CRC Press/Taylor \& Francis, Boca Raton, FL, USA, pp. 217-237. https://digitalcommons.unl.edu/icwdm_usdanwrc/2006.

Klug, P.E., Homan, H., 2020. Movement behavior of radio-tagged European starlings in urban, rural, and exurban landscapes. Human-Wildlife Interactions 14 (3), 398-408.

Koul, O., Cuperus, G.W., Elliott, N., 2008. Areawide Pest Management: Theory and Implementation. CABI Publishing, Wallingford, UK, p. 590.

Lamichhane, J.R., Debaeke, P., Steinberg, C., et al., 2018. Abiotic and biotic factors affecting crop seed germination and seedling emergence: a conceptual framework. Plant Soil 432, 1-28. https://doi.org/10.1007/s11104-018-3780-9.

Lamichhane, J.R., 2021. Post-emergence seedling damage due to vertebrate pests and its impact on soybean establishment. PeerJ 9, e11106. https://doi.org/10.7717/ peerj.11106.

Laundre, J.W., Hernandez, L., Ripple, W.J., 2010. The landscape of fear: ecological implications of being afraid. Open Ecol. J. 3, 1-7. https://doi.org/10.2174/ 1874213001003030001

Lindell, C.A., Steensma, K.M.M., Curtis, P.D., Boulanger, J.R., Carroll, J.E., Burrows, C., Lusch, D.P., Rothwell, N.L., Wieferich, S.L., Henrichs, H.M., Leigh, D.K., Eaton, R.A., Linz, G.M., 2016. Proportions of bird damage in tree fruits are higher in low-fruitabundance contexts. Crop Protect. 90, 40-48. https://doi.org/10.1016/j. cropro.2016.08.011.

Lindell, C., Eaton, R.A., Howard, P.H., Roels, S.M., Shave, M.E., 2018. Enhancing agricultural landscapes to increase crop pest reduction by vertebrates. Agric. Ecosyst. Environ. 257, 1-11. https://doi.org/10.1016/j.agee.2018.01.028.

Linz, G.M., Hulke, B.S., Kantar, M.B., Homan, H.J., Stupar, R.M., Wyse, D.L., 2014. Potential Use of Perennial Sunflower to Reduce Blackbird Damage to Sunflower. In: Timm, R.M., O'Brien, J.M. (Eds.), Proceedings of the 26th Vertebrate Pest Conference. University of California at Davis, CA, USA, pp. 356-359. https://digita lcommons.unl.edu/icwdm usdanwrc/1797.

Linz, G.M., Avery, M.L., Dolbeer, R.A., 2017. Ecology and Management of Blackbirds (Icteridae) in North America. CRC Press/Taylor \& Francis, Boca Raton, FL, USA.

Linz, G.M., Bucher, E.H., Canavelli, S.B., Rodriguez, E., Avery, M.L., 2015. Limitations of population suppression for protecting crops from bird depredation: a review. Crop Protect. 76, 46-52. https://doi.org/10.1016/j.cropro.2015.06.005.
Linz, G.M., Hanzel, J.J., 1997. Birds and Sunflower. Sunflower Technology and Production. Agronomy Monograph, American Society of Agronomy, Crop Science Society of America, Soil Science Society of America, Madison, WI, USA, pp. 381-394. https:// doi.org/10.2134/agronmonogr35.c7.

Linz, G.M., Homan, H.J., 2011. Use of glyphosate for managing invasive cattail (Typha spp.) to disperse blackbird (Icteridae) roosts. Crop Protect. 30 (2), 98-104. https:// doi.org/10.1016/j.cropro.2010.10.003.

McKee, S.C., Shwiff, S.A., Anderson, A.M., 2021. Estimation of wildlife damage from federal crop insurance data. Pest Manag. Sci. 77, 406-416.

Månsson, J., 2017. Lethal scaring - behavioral and short-term numerical response of greylag goose Anser anser. Crop Protect. 96, 58-264. https://doi.org/10.1016/j. cropro.2017.03.001.

McIvor, D.E., Conover, M.R., 1994. Impact of greater sandhill cranes foraging on corn and barley crops. Agric. Ecosyst. Environ. 49, 233-237.

Montràs-Janer, T., Knape, J., Nilsson, L., Tombre, I., Pärt, T., Månsson, J., 2019. Relating national levels of crop damage to the abundance of large grazing birds: implications for management. J. Appl. Ecol. 56, 2286-2297. https://doi.org/10.1111/13652664.13457.

Murton, R.K., 1965. The Wood-Pigeon. Collins, London, UK.

Murton, R.K., Bucher, E.H., Nores, M., Gómez, E., Reartes, J., 1974. The ecology of the eared dove (Zenaida auriculata) in Argentina. Condor 76 (1), 80-88. https://doi.org/ $10.2307 / 1365986$.

Orians, G., Angell, T., 1985. Blackbirds of the Americas. University of Washington Press, USA.

Peer, B.D., Homan, H.J., Linz, G.M., Bleier, W.J., 2003. Impact of blackbird damage to sunflower: bioenergetic and economic models. Ecol. Appl. 13 (1), 248-256. https:// doi.org/10.1890/1051-0761(2003)013[0248:IOBDTS]2.0.CO, 2.

Radtke, T.M., Dieter, C.D., 2011. Canada goose crop damage abatement in South Dakota. Human-Wildlife Interactions 5, 315-320.

Robin, N., 2011. Dégâts d'oiseaux sur grandes cultures 2750 agriculteurs témoignent. Perspect. Agric. 375, 30-33.

Rodríguez, E., Tiscornia, G., y Olivera, L., 2011. Disminución del daño por aves en pequeños predios. Serie FPTA-INIA 29 (63), 978-9974-38-322-7.

Runge, M.C., Sauer, J.R., 2017. Allowable Take of a Red-Winged Blackbirds in the Northern Great Plains. In: Linz, G.M., Avery, M.L., Dolbeer, R.A. (Eds.), 2017. Ecology and Management of Blackbirds (Icteridae) in North America. CRC Press/ Taylor \& Francis, Boca Raton, FL, USA, pp. 191-206.

Sarvia, F., De Petris, S., Borgogno-Mondino, E., 2020. A Methodological Proposal to Support Estimation of Damages from Hailstorms Based on Copernicus Sentinel 2 Data Times Series. In: International Conference on Computational Science and its Applications. Springer, Cham, pp. 737-751.

Sausse, C., Chevalot, A., Lévy, M., 2021. Hungry Birds Are a Major Threat for Sunflower Seedlings in France. Crop Protect. iIn this issue).

Sausse, C., Robert, C., 2017. Le pigeon ramier, principal bioagresseur du tournesol. Phytoma 704, 34-38.

Schaible, D., Dieter, C.D., Losco, R., Mammenga, P., 2005. Quantifying crop damage by giant Canada geese in Day County, South Dakota, 2003. Proc. South Dakota Acad. Sci. South Dakota Academy of Sciences 259-264.

Schillinger, W.F., Werner, S.J., 2016. First report of horned lark damage to canola seedings. Ind. Crop. Prod. 89, 465-467.

Simonsen, C.E., Madsen, J., Tombre, I.M., Nabe-Nielsen, J., 2016. Is it worthwhile scaring geese to alleviate damage to crops? - an experimental study. J. Appl. Ecol. 53, 916-924. https://doi.org/10.1111/1365-2664.12604.

Slater, P., 2001. Breeding ecology of a suburban population of Woodpigeons Columba palumbus in northwest England. Hous. Theor. Soc. 48 (3), 361-366.

Taylor, A.H., 2014. Corvid cognition. WIREs Cognitive Science 5 (3), 361-372. https:// doi.org/10.1002/wcs.1286.

Tefft, B.C., Gregonis, M.A., Eriksen, R.E., 2005. Assessment of crop depredation by wild turkeys in the United States and Ontario, Canada. Wildl. Soc. Bull. 33, 590-595.

Thibord, J.B., Cabeza Orcel, P., 2020. Lutte contre les dégâts de corvidés en maïs : combiner les leviers avant le semis. Perspect. Agric. 476, 26-27.

Ward, P., Zahavi, A., 1973. The importance of certain assemblages of birds as "information-centres" for food-finding. Ibis 115 (4), 517-534. https://doi.org/ 10.1111/j.1474-919X.1973.tb01990.x.

Werner, S.J., Linz, G.M., Tupper, S.K., Carlson, J.C., 2010. Laboratory efficacy of chemical repellents for reducing blackbird damage in rice and sunflower crops. J. Wildl. Manag. 74 (6), 1400-1404.

Whittingham, M.J., Krebs, J.R., Swetnam, R.D., Vickery, J.A., Wilson, J.D., Freckleton, R. P., 2007. Should conservation strategies consider spatial generality? Farmland birds show regional not national patterns of habitat association. Ecol. Lett. 10 (1), 25-35. https://doi.org/10.1111/j.1461-0248.2006.00992.x.

Wilson, E.A., Leboeuf, E.A., Weaver, K.M., LeBlanc, D.J., 1989. Delayed seeding for reducing blackbird damage to Sprouting rice in Southwestern Louisiana. Wildl. Soc. Bull. 17 (2), 165-171.

Wilson, J.D., Morris, A.J., Arroyo, B.E., Clark, S.C., Bradbury, R.B., 1999. A review of the abundance and diversity of invertebrate and plant foods of granivorous birds in northern Europe in relation to agricultural change. Agric. Ecosyst. Environ. 75 (1), $13-30$. 